\title{
COLOR VARIATION AMONG NESTLING BROWN-HEADED COWBIRDS (MOLOTHRUS ATER) DOES NOT REFLECT DIFFERENTIAL SUCCESS WITH HOSTS IN TEXAS
}

\author{
Kevin Ellison, ${ }^{1}$ Spencer G. Sealy, and Hope R. McGaha \\ Department of Zoology, University of Manitoba, Winnipeg, Manitoba R3T 2N2, Canada
}

\begin{abstract}
As brood parasites, nestling Brown-headed Cowbirds (Molothrus ater) may exhibit characters that improve their fledging success when reared alongside host young. The coloration of mouthparts of nestlings can influence adult care and, thus, the polymorphism of yellow or white rictal flanges among nestling Brown-headed Cowbirds may reflect differential success with different hosts on the basis of flange color. Moreover, because Brown-headed Cowbirds in the southern United States co-occur with Bronzed Cowbirds ( $M$. aeneus), whose young have white flanges, cowbird nestlings' flange colors may reflect a means for reducing interspecific competition through partitioning of host species on the basis of nestling flange color. To determine whether flange color influences cowbird fledging success with hosts of either color, we recorded the flange colors of cowbirds and their hosts at a site in Texas. We also tested whether flange color was influenced by nestling sex. Most hosts of Brown-headed Cowbirds had young with yellow flanges $(81 \%$, $n=16$ spp.), yet Brown-headed Cowbirds with white flanges were more common $(61 \%, n=107)$. Bronzed Cowbirds parasitized primarily species whose young had white flanges ( $86 \%, n=348$ eggs). Despite the differential use of hosts with regard to flange color, the frequencies of each were similar among nestling and juvenile Brown-headed Cowbirds. Likewise, the frequencies of each color did not differ significantly between the sexes. Therefore, we suggest that a flange color matching that of nestmates is not strongly selected for by hosts. Received 3 October 2003, accepted 25 April 2006.
\end{abstract}

Key words: bill color, Bronzed Cowbird, Brown-headed Cowbird, Molothrus aeneus, $M$. ater, nestling discrimination, polymorphism.

\section{La Variación del Color entre Polluelos de Molothrus ater no Refleja Éxito Diferencial al Ser Criados por Especies Hospederas en Texas}

\begin{abstract}
Resumen. - Como un ave parásita de nido, Molothrus ater puede exhibir caracteres que aumentan su éxito de emplumamiento cuando sus polluelos son criados junto a los de su hospedero. La coloración de la boca de los polluelos puede influenciar el cuidado por parte de los padres, por lo que el polimorfismo de la coloración blanca o amarilla de la parte lateral de la boca de los polluelos de $M$. ater podría conducir a diferencias en el éxito al ser criados por especies hospederas. Además, debido a que M. ater coexiste con $M$. aeneus, cuyos polluelos tienen la parte lateral de la boca de color blanco, la coloración de esta parte en los polluelos de Molotrus podría reflejar un medio por el cual se reduce la competencia interespecífica a través de la partición de las especies hospederas. Para determinar si la coloración de la parte lateral de la boca influencia el éxito de emplumamiento de los polluelos con hospederos de distintos
\end{abstract}

\footnotetext{
${ }^{1}$ Present address: Department of Wildlife Ecology, University of Wisconsin, Madison, Wisconsin 53706, USA. E-mail: ksellison@wisc.edu
} 
colores, registramos esta coloración de los polluelos de Molothrus y de sus hospederos en una localidad en Texas. También probamos si esta coloración estaba influenciada por el sexo de los polluelos. La mayoría de las especies hospederas de $M$. ater tuvieron polluelos con la parte lateral de la boca de color amarillo $(81 \%, n=16 \mathrm{spp}$.), pero los polluelos de $M$. ater tuvieron una mayor frecuencia de coloración blanca ( $61 \%$, $n=107)$. Molothrus aeneus parasitó principalmente a especies cuyos polluelos tenían la parte lateral de la boca de color blanco $(86 \%, n=348$ huevos). A pesar del uso diferencial de hospederos con respecto a la coloración de la boca, las frecuencias de cada color fueron similares entre polluelos y juveniles de $M$. ater. De modo similar, las frecuencias de cada color no fueron diferentes entre sexos. Sugerimos que un color de la boca igual al de los polluelos compañeros en el nido no es un rasgo que se encuentra bajo una presión selectiva fuerte por parte de los hospederos.

After hatching, features of the gape and associated movements are some of the earliest forms of communication between young and adult songbirds. Internal (gape lining, mouth markings or nodules or both) and external (tomium proper, rictal flange; see Fig. 1) mouthparts of nestlings are important features of nestling communication. For some species, gape coloration is an important indicator of nestling physiological status (Kilner 1998, Clotfelter et al. 2003, Saino et al. 2003). In species exposed to brood parasitism, coloration of both internal and external mouthparts may be associated with discrimination of parasitic young (Nicolai 1974, Payne et al. 2001). Brood parasites, therefore, provide interesting cases for the study of communication between adults and their young, because dissimilar parasitic young that are often reared at a reproductive cost to the hosts (Dearborn et al. 1998, Lorenzana and Sealy 1999) may reveal the primary mechanisms by which nestlings convey their needs to caregivers (Dearborn and Lichtenstein 2002). The external mouthparts of young of most songbirds are usually white or yellow, and the color does not vary within each species (Ficken 1965, Rothstein 1978, Skutch 1976). Therefore, it is noteworthy that the nestlings of several brood parasites are polymorphic in the color of their mouthparts (Cuculus: Gill 1998; Vidua: Nicolai 1974, Payne et al. 2001; Molothrus: Fraga 1978, Rothstein 1978).

Selection from hosts that shapes the appearance of nestling brood parasites represents coevolution between parasites and hosts (Rothstein 1990). For instance, the young of each species of indigobird and whydah (Vidua spp.) exhibit remarkably differently colored and patterned internal mouthparts that are maintained, presumably through selection by hosts, within specific host-parasite lines (see Payne et al. 2001). By contrast, young Brown-headed Cowbirds (Molothrus ater) and Shiny Cowbirds (M. bonariensis) have white or yellow rictal flanges (Fig. 1; Fraga 1978, Rothstein 1978) and are often reared by hosts whose young exhibit either flange color. A key difference between Vidua and these cowbirds may be attributed to the low incidence of nestling discrimination among cowbird hosts. This reflects primarily the lack of time for more highly coevolved interactions between these two more recently derived cowbird species and their hosts, in contrast to that described among the more basal cowbirds and their hosts (Rothstein et al. 2002).

Presuming that selection for nestling appearance is absent among the generalist Shiny and Brown-headed cowbirds, it appears likely that, rather than being fixed and of one color, population flange-color frequencies should vary. Instead, Brown-headed Cowbirds apparently exhibit geographic trends in body size and flange color with young of the smallest subspecies, $M$. $a$. obscurus, having predominantly yellow flanges, whereas those of $M$. a. artemisiae and M. a. ater are mostly white (Rothstein 1978; Fig. 2). However, few studies have recorded Brown-headed Cowbird flange color outside western North America (Rothstein 1978, Ortega and Cruz 1992, Ward and Smith 1998).

Flange color may affect nestling foodacquisition (Immelmann et al. 1977, Stevens 1982, Kilner 1998) through the cowbird nestling's flange-color matching (Rothstein 1978, Ward and Smith 1998) or differing from (Rothstein 1978, Stevens 1982) its nestmate's flange color. For instance, southern populations of Brown-headed Cowbirds with 


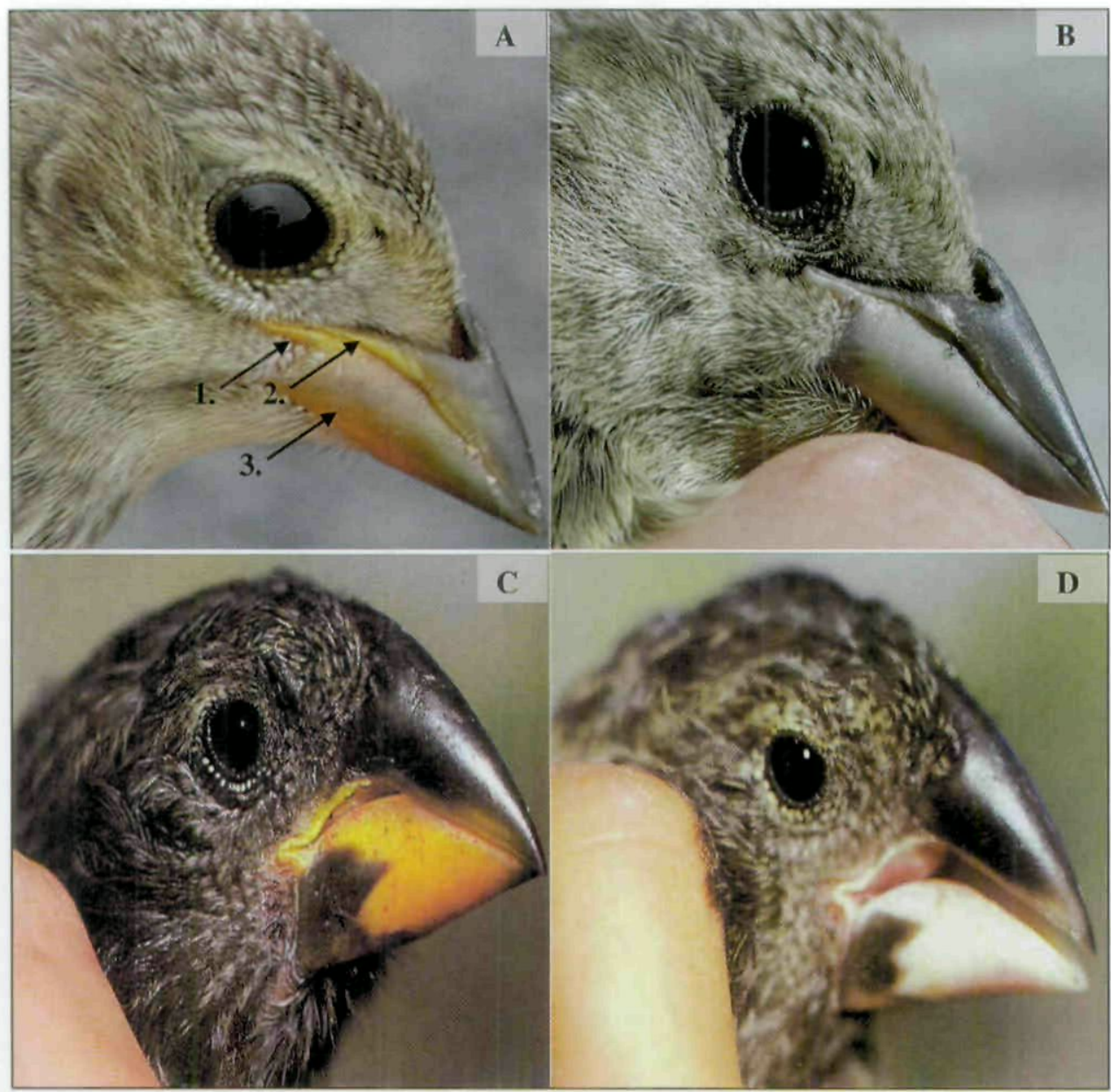

Fig. 1. Yellow and white color morphs of juvenile Brown-headed Cowbirds (A and B; present study) and Large Ground-Finches (Geospiza magnirostris; C and D, from Grant 1999). Arrows in A indicate external mouthparts that varied in pigmentation: 1 = rictal flange, $2=$ tomium proper, and $3=$ lower mandible.

predominantly yellow flanges co-occur with northern populations of the Bronzed Cowbird (M. aeneus), whose young have white flanges (Friedmann 1929, Rothstein 1978, Carter 1986). Therefore, the predominance of yellowflanged young may be a character displacement promoted by differential reproductive success with hosts of one particular flange color (Rothstein 1978). To test whether cowbirds parasitize hosts differentially on the basis of flange color, we recorded the flange colors of young cowbirds and their hosts at a site in southern Texas where Brown-headed and Bronzed cowbirds co-occur. We predicted that if differential success with hosts is selected, (1) nestling flange-color of hosts of each cowbird should match significantly more often and (2) cowbirds whose color matches that of the majority of hosts should fledge more often than cowbirds with the color of the minority of hosts. Also, because the color of nestling skin and external mouthparts is determined by a sex-linked gene in a captive strain of Zebra Finches (Taeniopygia guttata; Birkhead et al. 1988, Kilner 1998), we sexed cowbirds to determine whether either flange color was disproportionately more common among males, as expected for a sex-linked trait. 


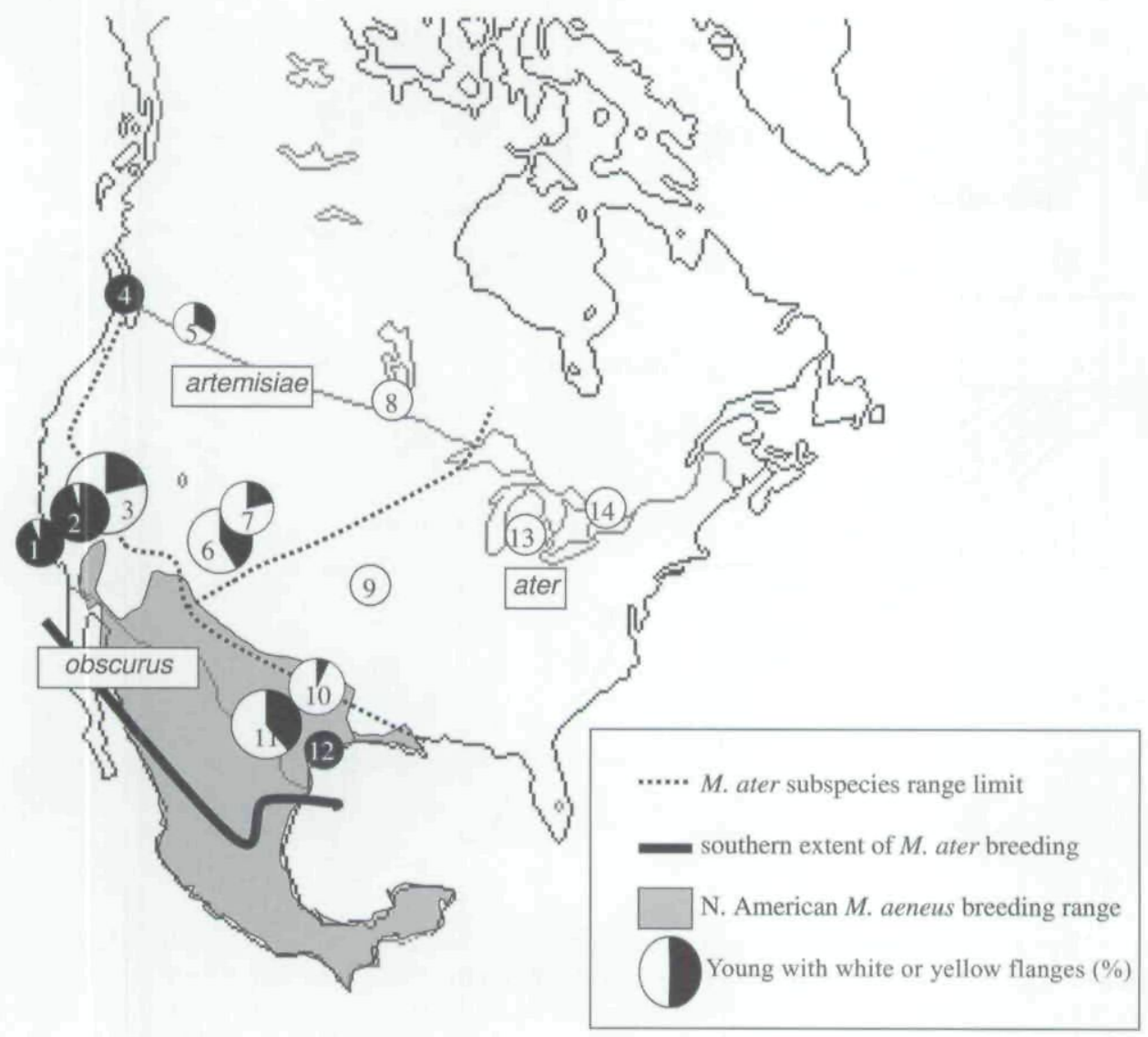

FIG. 2. Geographic variation in the ratios of Brown-headed Cowbird rictal flange color, illustrated in relation to sample size (black = proportion of yellow-flanged young) by subspecies, after Rothstein $(1978,1994)$. Ratios measured at: Santa Barbara, California (1) (Rothstein 1978), western (2) and eastern (3) slopes of the Sierra Nevada, California (Fleischer and Rothstein 1988); Mandarte Island (4), British Columbia (J. N. M. Smith unpubl. data) and Okanagan Valley (5), British Columbia (Ward and Smith 1998); La Plata County (6), Colorado (C. P. Ortega and J. C. Ortega unpubl. data) and Boulder County (7), Colorado (Ortega and Cruz 1992); Delta Marsh (8), Manitoba (S. G. Sealy unpubl. data); Kansas (9) (Rothstein 1978, W. E. Jensen unpubl. data); Bell (10), Kinney (11), and San Patricio (12) counties, Texas (present study); and Michigan (13) and Ontario (14) (Rothstein 1978).

\section{MeTHODS}

\section{FLANGE-COLOR RATIOS}

We recorded flange colors of young cowbirds and their hosts at Fort Clark Springs, Kinney County, Texas $\left(29^{\circ} 18^{\prime} \mathrm{N}, 100^{\circ} 43^{\prime} \mathrm{W}\right.$; Fig. 3). This site is dominated by lawns, huisache (Acacia minuata), and honey mesquite (Prosopis glandu$l o s a)$, as well as riparian habitats of pecan (Carya illinoensis) and live oak (Quercus virginiana). To assess the frequency of each flange color, we searched for cowbird eggs and young during four breeding seasons, 1999-2002. Both cowbird species were common at the site, and each year more than 50 eggs of each species were found within the 40-ha primary study site (see Ellison 2004). Young Bronzed Cowbirds were distinguished from Brown-headed Cowbirds by appearance and vocalizations (Friedmann 1929, Carter 1986). Almost all young were found within $1 \mathrm{~km}$ of the area where cowbird eggs were collected for another study. Having assigned maternity using microsatellite DNA 


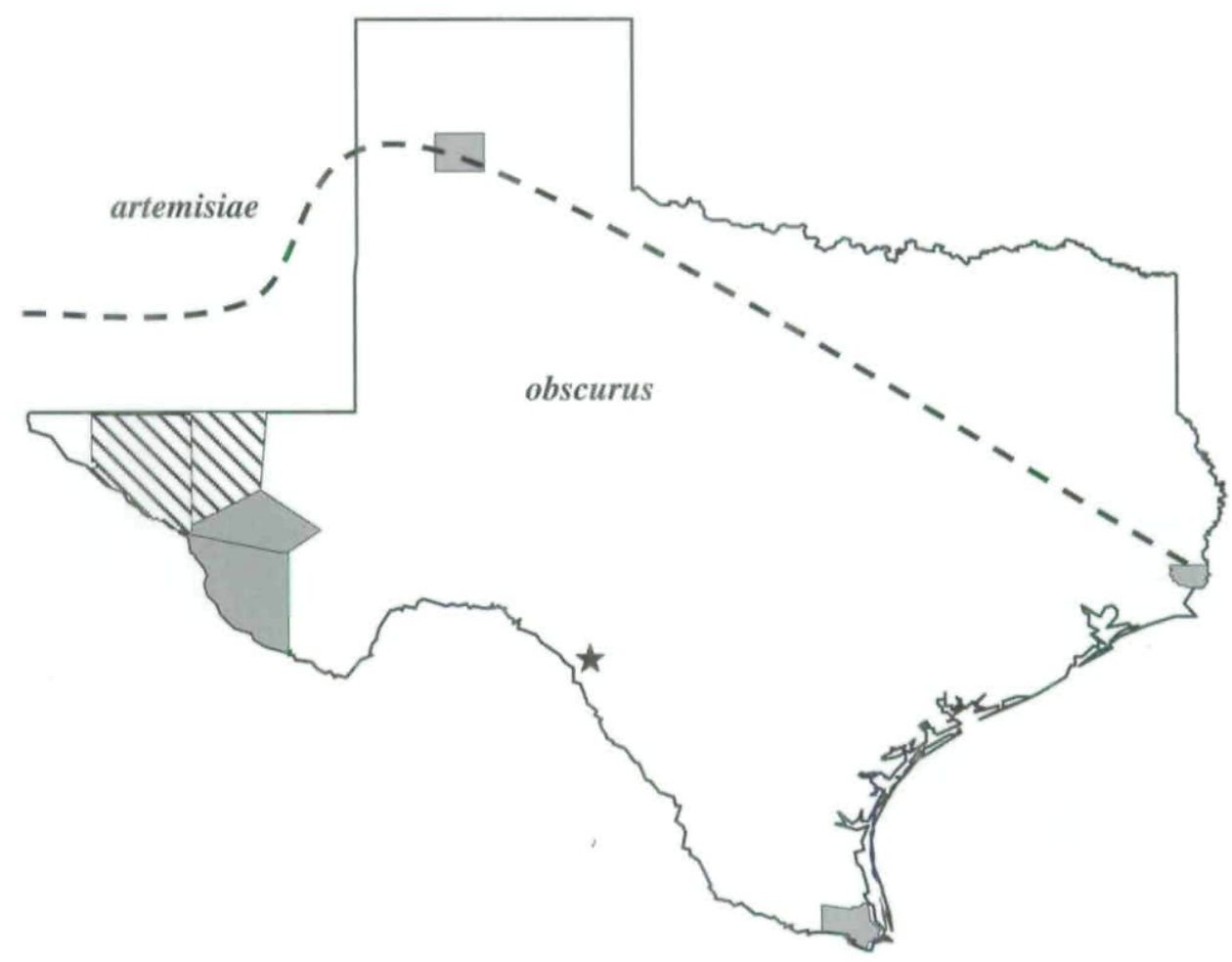

Fig. 3. Approximate breeding ranges of subspecies of Brown-headed Cowbird in Texas, based on Oberholser (1974). Star indicates the location of the present study near Fort Clark Springs, Kinney County. Oberholser (1974) included the subspecies M. a. buphilus, which is not recognized by the American Ornithologists' Union (2000), but we equated its distribution with that of M. a. obscurus (hatched counties). Oberholser's (1974) type specimens are from the shaded counties.

markers (Ellison 2004), we measured flange color and assigned sex for the young of at least six Brown-headed Cowbirds within the 40-ha area each year. However, it is likely that we sampled the young of more females, because the genetic analysis involved young from the smaller primary study area and we captured 192 females. Of the 126 females that were color banded, 28 were resighted in the 40 -ha area of the primary site and likely bred locally.

K.E. visually assigned flange color as yellow or white (sensu Rothstein 1978) for cowbirds observed in nests or hatched in an incubator. We used a general dichromatic categorization because no cowbirds were detected with intermediate flange colors and intermediates have rarely been observed in other studies (i.e., $<1 \%$, $n=624$; Rothstein 1978, Stevens 1982, Fleischer and Rothstein 1988). K.E. also recorded flange color of fledged young that were being fed by hosts and those captured by hand, caught in walk-in traps, or mist netted. We captured 491 Brown-headed Cowbirds and 157 Bronzed Cowbirds, a portion of which were blood sampled for this study and a concurrent study of host use (Ellison 2004). Young cowbirds were uniquely color banded and measured, and a $15-\mu \mathrm{L}$ sample of blood was taken from the alar vein (sensu Alderson et al. 1999).

To better assess broadscale geographic variation among flange-color ratios, we summarized published and unpublished data. Also, we present data only from locales where flange color of more than four birds was reported by Rothstein (1978; his sites 1, 13-16, and 20-21; see our Fig. 2; sites 1, 9, and 13-14). Given the pattern of introgression of $M . a$. obscurus and $M$. a. artemisiae documented by Fleischer and Rothstein (1988), we report data from only their two most distant sites: Bishop $(n=93)$ and Lake Edison $(n=60)$ on the east and west slopes of the Sierra Nevada Range, California, respectively (Fig. 2, sites 
2-3). We also used data from Boulder County, Colorado (Ortega and Cruz 1992). Unpublished data were obtained from Mandarte Island, British Columbia $\left(48^{\circ} 38^{\prime} \mathrm{N}, 123^{\circ} 17^{\prime}\right.$ W; J. N. M. Smith); San Juan Basin Research Center, La Plata County, Colorado $\left(37^{\circ} 14^{\prime} \mathrm{N}, 108^{\circ} 2^{\prime} \mathrm{W}\right.$; C. P. Ortega and J. C. Ortega); Delta Marsh, Manitoba $\left(50^{\circ} 12^{\prime} \mathrm{N}\right.$, $98^{\circ} 12^{\prime}$ W; S. G. Sealy); Konza Prairie Reserve, Kansas $\left(39^{\circ} 5^{\prime} \mathrm{N}, 9^{\circ} 33^{\prime} \mathrm{W}\right.$; W. E. Jensen); Fort Hood, Bell County, Texas $\left(31^{\circ} 8^{\prime} \mathrm{N}, 97^{\circ} 33^{\prime} \mathrm{W}\right.$; K. Ellison and S. G. Summers); and the Rob and Bessie Welder Wildlife Foundation Refuge, San Patricio County, Texas $\left(28^{\circ} 0^{\prime} \mathrm{N}, 97^{\circ} 5^{\prime} \mathrm{W} ; \mathrm{H}\right.$. R. McGaha).

\section{FLANGE-COLOR INHERITANCE}

If sex-linked, a dominant trait would be more common among males because female birds are heterogametic. To determine flange-color frequencies by sex, we used DNA extracted from blood (see Alderson et al. 1999) to sex young incapable of sustained flight. Sex was determined through polymerase chain reaction (PCR) amplification of chromo-helicase-DNA binding (CHD1) genes from the avian $\mathrm{W}$ and $\mathrm{Z}$ sex chromosomes electrophoresced on $2 \%$ agarose gels (Griffiths et al. 1998); CHD-analysis resulted in two distinct bands for females, one for males, and none when PCR amplification failed. We verified the accuracy of this technique with DNA from five adults of each sex. Also, we used wing length to identify the sex of most juveniles. Hill (1976) established that wing length could be used to assign sex of juvenile cowbirds. Because of geographic variation in body size, we used the genetic technique (for 17 juveniles at our site) and gonadal inspection (270 juveniles collected at Fort Hood, Texas; see Summers et al. 2006) to establish a wing-length criterion for assigning sex for the birds at our site. Using the criterion that birds with wing length $>99 \mathrm{~mm}$ were males, we assigned only two males $(0.7 \%)$ to the incorrect sex. Thus, we were confident that the criterion was valid and that birds with wings $>99 \mathrm{~mm}$ did not need to be sexed genetically.

\section{Results}

\section{FLANGE-COLOR RATIOS}

Despite the expectation of mostly yellowflanged young Brown-headed Cowbirds, fewer yellow-flanged young were recorded in Texas (39\% yellow-flanged at Fort Clark Springs, $n=107$ ). Flanges at other sites conformed to expectations based on subspecies (Rothstein 1978): Welder Wildlife Foundation Refuge in Texas $(100 \%$ yellow-flanged, $n=14)$, Kansas ( $0 \%$ yellow-flanged, $n \approx 50$ ), and Manitoba $(0 \%$ yellow-flanged, $n \approx 20$ ). However, exceptions were recorded nearer the putative boundaries of subspecies' ranges in Colorado: San Juan Basin Research Center (39\% yellow-flanged, $n=$ $172)$ and Texas: Fort Hood (1\% yellow-flanged, $n=97$ ).

We observed significantly more white- than yellow-flanged cowbird young (65 white: 42 yellow, $G=5.0, P=0.03$ ). The color frequencies did not change significantly between the nestling (20:10) and juvenile (45:32) stages $(G=1.72, P=0.20)$. Overall, Brown-headed Cowbirds parasitized at least 16 species (Table 1 ), but $76 \%$ of the eggs and young found $(n=382)$ were from Bell's Vireo (Vireo bellii) and Blue-gray Gnatcatcher (Polioptila caerulea) nests, both of which have yellow-flanged young. Host and cowbird nestlings' flange colors were not associated directly; 13 of the 16 species parasitized had yellow-flanged young, whereas white-flanged cowbird young predominated among hatchlings (11 white: 3 yellow) and juveniles (45 white: 32 yellow). Likewise, young in Colorado had predominantly white flanges (Fig. 2).

\section{FLANGE-COLOR INHERITANCE}

Flange-color frequencies varied for males and females as expected under sex-linkage (males, 24 white: 9 yellow; females, 13 white: 11 yellow); however, the difference was not significant for our small sample (Yates corrected $\chi^{2}=1.37$, $\mathrm{df}=1, P=0.24)$. In 2002 , we noted the presence of yellow-pigmented feathers on the abdomen, breast, throat, and supercilium of 13 birds. We had not noticed this variation previously, and the absence of yellowish feathers appeared to be much more common. Judging from our sample of 15 cowbirds, yellowish feathers were not associated with flange color or sex: 13 birds had yellowish feathers (10 yellow-flanged [6M: $4 \mathrm{~F}]$ and 3 white-flanged [2M: $1 \mathrm{~F}]$ ). Both young birds without yellowish feathers had white flanges. All 77 Bronzed Cowbird young had white flanges. 
TABLE 1. Species parasitized by Brown-headed and Bronzed cowbirds, listed by host flange color. Fledgling tallies do not include those detected as eggs. Only nests available during cowbird laying (23 April-27 July, 1999-2002) are presented. Northern Mockingbird (Mimus polyglottos) nests ( $n=$ 226) were not parasitized; Northern Mockingbird young have yellow flanges,

\begin{tabular}{|c|c|c|c|c|c|}
\hline \multirow[b]{2}{*}{ Host species } & \multirow[b]{2}{*}{$\begin{array}{l}\text { Nests } \\
(n)\end{array}$} & \multicolumn{2}{|c|}{ Brown-headed } & \multicolumn{2}{|c|}{ Bronzed } \\
\hline & & $\begin{array}{l}\text { Eggs } \\
(n)\end{array}$ & $\begin{array}{l}\text { Fledglings } \\
\qquad(n)\end{array}$ & $\begin{array}{l}\text { Eggs } \\
(n)\end{array}$ & $\begin{array}{l}\text { Fledglings } \\
(n)\end{array}$ \\
\hline \multicolumn{6}{|c|}{ Yellow flanges } \\
\hline Black Phoebe (Sayornis nigricans) & 4 & 1 & 0 & 0 & 0 \\
\hline Vermilion Flycatcher (Pyrocephalus rubinus) & 179 & 18 & 16 & 0 & 0 \\
\hline White-eyed Vireo (Vireo griseus) & 9 & 4 & 5 & 0 & 0 \\
\hline Bell's Vireo (V. bellii) & 180 & 188 & 21 & 0 & 0 \\
\hline Bewick's Wren (Thryomanes bewickii) & 8 & 0 & 1 & 1 & 0 \\
\hline Blue-gray Gnatcatcher (Polioptila caerulea) & 20 & 25 & 56 & 0 & 0 \\
\hline Black-tailed Gnatcatcher ( $P$. melanura $)$ & 2 & 1 & 1 & 0 & 0 \\
\hline Summer Tanager (Piranga rubra) & 18 & 0 & 0 & 5 & 4 \\
\hline Chipping Sparrow (Spizella passerina) & 30 & 0 & 2 & 1 & 0 \\
\hline Lark Sparrow (Chondestes grammacus) & 330 & 5 & 2 & 0 & 0 \\
\hline Northern Cardinal (Cardinalis cardinalis) & 72 & 3 & 0 & 38 & 6 \\
\hline Pyrrhuloxia (C. sinuatus) & 4 & 0 & 0 & 2 & 2 \\
\hline Blue Grosbeak (Passerina caerulea) & 16 & 6 & 2 & 2 & 0 \\
\hline Painted Bunting $(P$. ciris $)$ & 58 & 18 & 1 & 0 & 0 \\
\hline Indigo Bunting ( $P$. cyanea $)$ & 1 & 1 & 0 & 0 & 0 \\
\hline House Finch (Carpodacus mexicanus) & 49 & 0 & 0 & 1 & 0 \\
\hline \multicolumn{6}{|c|}{ White flanges } \\
\hline Yellow-breasted Chat (Icteria virens) & 38 & 0 & 1 & 8 & 0 \\
\hline Black-throated Sparrow (Amphispiza bilineata) & 3 & 2 & 0 & 0 & 0 \\
\hline Orchard Oriole (Icterus spurius) & 61 & 1 & 0 & 101 & 36 \\
\hline Hooded Oriole (I. cucullatus) & 104 & 1 & 0 & 167 & 25 \\
\hline Bullock's Oriole (I. bullockii) & 58 & 0 & 0 & 22 & 6 \\
\hline Totals & 1,244 & 274 & 108 & 348 & 79 \\
\hline
\end{tabular}

\section{Discussion}

\section{Flange Color}

We found that (1) a local Brown-headed Cowbird population may vary in nestling flange color, (2) flange-color frequencies varied between males and females, and (3) flange color apparently is not under strong selection from hosts. The variable color frequencies between sexes and the apparent lack of strong selection on color from hosts further suggest that flange-color frequencies would vary within populations, as found among Shiny Cowbirds (Fraga 1978). However, Brown-headed Cowbird populations usually are only white or yellow across broad geographic areas (Rothstein 1978, Pyle 1997; Fig. 2).

In Texas, young Brown-headed Cowbirds had either white or yellow flanges, though they were not in a contact zone between subspecies that previously experienced presumably little or no gene flow (see Fleischer and Rothstein 1988). Gene flow may explain the presence of the white morph, as Fleischer and Rothstein (1988) showed that introgression between M. a. obscurus and M. a. artemisiae was rapid and mostly unidirectional. Human land-use practices apparently have modified breeding and wintering ranges of several icterids (Stepney and Power 1973, Cruz et al. 1985, Rothstein 1994, Whetje 2003). Therefore, one subspecies may be expanding into areas once dominated by another. In this case, genes from $M$. a. ater would be entering areas once dominated by those of $M$. a. obscurus, and changes in flange color would reflect relatively recent gene flow. It is possible that some cowbirds breed before migrating north; however, the measurements 
of adult Brown-headed Cowbirds and eggs at our site were characteristic of the smallest subspecies, M. a. obscurus (K. Ellison unpubl. data). Likewise, Summers et al. (2006) found that some larger females, presumably not $M$. a. obscurus, remained at Fort Hood from March through June, but none had enlarged ovaries. Therefore, the presence of both colors suggests that white flanges represent a polymorphism within M. a. obscurus in Texas, similar to that among Shiny Cowbirds (Fraga 1978).

This is likely, because nestling discrimination is rare and presumably would result in increased costs if mistakes in discrimination were made (Lotem 1993; but see Langmore et al. 2003). The lack of strong selection for flange color is interesting, because Brown-headed and Bronzed cowbirds almost exclusively parasitized hosts with yellow- and white-flanged young, respectively. Nonetheless, with no clear difference in fledging success of either morph (as inferred from the occurrence of juveniles), flange color does not seem to reflect a character displacement at our site. Alternatively, we suggest that host use may reflect differential parasitism on the basis of host body size and possibly phylogeographic history (Friedmann 1929).

\section{Flange-COLOR Ratios}

Because significantly more white-flanged Brown-headed Cowbirds were produced each year, local adaptation would be supported if hosts with white-flanged young were differentially parasitized at our site. A positively assortative pattern seems unlikely, given that Brown-headed Cowbirds, which produced predominantly white-flanged young, regularly parasitized species whose young had yellow flanges (Table 1). The fledging success of cowbirds of either flange color did not differ significantly; however, our sample size was limited.

Alternatively, hosts may differentially feed young with a nonmatching flange color (Rothstein 1978, Stevens 1982). Indeed, Stevens (1982) experimentally manipulated flange colors of Red-winged Blackbirds (Agelaius phoeniceus) and Yellow-headed Blackbirds (Xanthocephalus xanthocephalus) and found that when yellow-flanged young were less common within a brood, they were fed more than their white-flanged nestmates. We lack the data to test either case directly and suggest further study involving manipulation of brood composition by recording host provisioning rates at nests that contain pairs of cowbirds with different combinations of flange colors.

We also have few data to address whether Bronzed Cowbirds fare as well with yellowflanged hosts, though Carter (1986) reported that this species fledged from nests of hosts of either color. Of 153 Bronzed Cowbird fledglings, only $50 \%$ were tended by species whose young have white flanges (Carter 1986). Moreover, the most frequent host recorded for Bronzed Cowbirds is the Northern Mockingbird (Mimus polyglottos; Lowther 1995), whose young have yellow flanges. We suggest that little selection is currently exerted by hosts on cowbird nestling flange color, because survival of Brown-headed Cowbirds at our site seemed to be unaffected by flange color.

\section{FLANGE-COLOR INHERITANCE}

Stevens (1982) and Ward and Smith (1998) noted that flanges in the zone of hybridization are mostly yellow, which suggests that the allele for yellow flange color is dominant over the allele for white. By contrast, our analysis suggests that yellow may be a sexinfluenced recessive trait, but controlled crosses of cowbirds with flanges of known color are required to confirm the mode of inheritance. Flange-color inheritance may be elucidated by studies of Darwin's finches (Geospiza), among which a visually similar color polymorphism occurs. Eight geospizid species were recorded with color-free (referred to as pink by Grant et al. [1979]) and yellow external mouthparts (Fig. 1) in $82 \%$ and $18 \%$ of young ( $n=1,874)$, respectively. With striking similarity to those of Brown-headed Cowbirds in Texas, the flangecolor frequencies of Medium Ground-Finches (Geospiza fortis) were close to those expected under sex-linkage (Grant 1999). However, young produced by adults with known bill colors violated expectations under simple sexlinkage (Grant 1999). Therefore, Grant (1999) suggested that color was controlled by at least two loci with epistasis. Our observations of yellow-flanged cowbirds, some with yellowtinged plumage, further suggest multilocus control of color traits.

Alternatively, as a potentially sex-influenced trait, color may be affected by androgen levels 
that can affect expression of xanthophyll pigments (Stoehr and Hill 2001, Faivre et al. 2003). Testosterone levels do not appear to vary such that geographic variation in flange color is likely to be affected (Hahn et al. 2005); nonetheless, the potential for variation exists in maternal provisioning of pigments (i.e., carotenoids in eggs; Bortolotti et al. 2003).

\section{Trait Maintenance}

Our results support Rothstein's (1978) suggestion that there are no major differences in cowbird fledging success, regardless of whether the young have white or yellow flanges. Alternatively, historical conditions may have favored one flange color or a polymorphism in flange color if cowbirds evolved with entirely different suites of host species, particularly species that now reject parasitism but may once have been important hosts. Thus, the present polymorphism would reflect evolutionary lag and be subject only to genetic drift. Interestingly, only two New World genera, Molothrus and Geospiza, are known to exhibit polymorphisms for nestling flange color, despite the potential for direct selection (host matching in Molothrus) or indirect selection (song types and bill size in Medium Ground-Finches). Because of the rarity of color polymorphisms among nonparasitic species, it seems plausible that selection has maintained this variation in cowbirds. Our data, however, support the lack of nestling discrimination among cowbird hosts, in line with the long-term pattern of generalist host use by individual Brown-headed Cowbirds (Gibbs et al. 1997). Further study of flange color may clarify our understanding of communication between young and adults.

\section{ACKNOWLedgments}

We thank the residents of Fort Clark Springs for allowing us to conduct our research in their community. We also thank W. E. Jensen, G. L. Norman, C. P. and J. C. Ortega, J. N. M. Smith, and S. G. Summers for unpublished data. M. Boyd, S. Coles, M. Cottam, S. Cyr, N. Marino, P. Sullivan, and A. Walleyn assisted in the field; H. L. Gibbs, L. DeSousa and L. Blanchard assisted in the lab; and D. Willard and curatorial staff at the Field Museum of Natural History prepared specimens. The manuscript benefited from comments by R. C. Fleischer, P. R. Grant, S. I. Rothstein, and an anonymous reviewer. This research was funded by a grant from the Natural Sciences and Engineering Research Council of Canada to S.G.S., University of Manitoba Graduate fellowships awarded to K.E. and H.R.M., Frank M. Chapman Memorial awards (American Museum of Natural History) to K.E., and an American Ornithologists' Union Graduate Student Award to H.R.M.

\section{Literature Cited}

Alderson, G. W., H. L. Gibbs, and S. G. Sealy. 1999. Parentage and kinship studies in an obligate brood parasitic bird, the Brownheaded Cowbird (Molothrus ater), using microsatellite DNA markers. Journal of Heredity 90:182-190.

American Ornithologists' Union. 2000. Forty-second supplement to the American Ornithologists' Union Check-list of North American Birds. Auk 117:847-858.

Birkhead, T. R., J. Pellat, and F. M. Hunter. 1988. Extra-pair copulation and sperm competition in the Zebra Finch. Nature 334:60-62.

Bortolotti, G. R., J. J. Negro, P. F. Surai, and P. Prieto. 2003. Carotenoids in eggs and plasma of Red-legged Partridges: Effects of diet and reproductive output. Physiological and Biochemical Zoology 76:367-374.

Carter, M. D. 1986. The parasitic behavior of the Bronzed Cowbird in South Texas. Condor 88:11-25.

Clotpelter, E. D., K. A. Schubert, V. Nolan, JR., AND E. D. Ketterson. 2003. Mouth color signals thermal state of nestling Darkeyed Juncos (Junco hyemalis). Ethology 109: 171-182.

Cruz, A., T. Manolis, and J. W. Wiley. 1985. The Shiny Cowbird: A brood parasite expanding its range in the Caribbean region. Pages 607-620 in Neotropical Ornithology (P. A. Buckley, M. S. Foster, E. S. Morton, R. S. Ridgely, and F. G. Buckley, Eds.). Ornithological Monographs, no. 36.

Dearborn, D. C., A. D. Anders, F. R. Thompson III, AND J. FAaborg. 1998. Effects of cowbird parasitism on parental provisioning and nestling food acquisition and growth. Condor 100:326-334.

Dearborn, D. C., and G. Lichtenstein. 2002. Begging behavior and host exploitation 
in parasitic cowbirds. Pages 361-387 in The Evolution of Begging: Competition, Cooperation and Communication (J. Wright and M. L. Leonard, Eds.). Kluwer Academic, Norwell, Massachusetts.

Ellison, K. 2004. Host use by sympatric cowbirds (Molothrus aeneus and M. ater). Ph.D. dissertation, University of Manitoba, Winnipeg.

Faivre, B., M. Préault, F. Salyadori, M. Théry, M. Gaillard, and F. Cézilly. 2003. Bill colour and immunocompetence in the European Blackbird. Animal Behaviour 65: 1125-1131.

FICKEN, M. S. 1965. Mouth color of nestling passerines and its use in taxonomy. Wilson Bulletin 77:71-75.

Fleischer, R. C., and S. I. Rothstein. 1988. Known secondary contact and rapid gene flow among subspecies and dialects in the Brown-headed Cowbird. Evolution 42: 1146-1158.

FragA, R. M. 1978. The Rufous-collared Sparrow as a host of the Shiny Cowbird. Wilson Bulletin 90:271-284.

Friedmann, H. 1929. The Cowbirds: A Study in the Biology of Social Parasitism. C. C. Thomas, Springfield, Illinois.

Gibis, H. L., P. Miller, G. Alderson, And S. G. Sealy. 1997. Genetic analysis of Brownheaded Cowbirds Molothrus ater raised by different hosts: Data from mtDNA and microsatellite DNA markers. Molecular Ecology 6:189-193.

GILL, B. J. 1998. Behavior and ecology of the Shining Cuckoo Chrysococcyx lucidus. Pages 143-151 in Parasitic Birds and Their Hosts: Studies in Coevolution (S. I. Rothstein and S. K. Robinson, Eds.). Oxford University Press, New York.

Grant, P. R. 1999. Ecology and Evolution of Darwin's Finches, 2nd ed. Princeton University Press, Princeton, New Jersey.

Grant, P. R., P. T. Boag, and D. Schluter. 1979. A bill color polymorphism in young Darwin's Finches. Auk 96:800-802.

Griffiths, R., M. C. Double, K. OrR, and R. J. G. DAwson. 1998. A DNA test to sex most birds. Molecular Ecology 7:1071-1075.

Hahn, D. C., J. S. Hatfield, M. A. Abdelnabi, J. M. Wu, D. IgL, AND M. A. Ottinger. 2005. Inter-species variation in yolk steroid levels and a cowbird-host comparison. Journal of Avian Biology 36:40-46.
Hill, R. A. 1976. Sex ratio and sex determination of immature Brown-headed Cowbirds. Bird-Banding 47:112-114.

Immelmann, K., A. Piltz, and R. Sossinka. 1977. Experimentelle untersushungen zur bedeutung der rachenzeichnung junger Zabrafinken. Zeitschrift für Tierpsychologie 45:210-218.

KILNER, R. 1998. Primary and secondary sex ratio manipulation by Zebra Finches. Animal Behaviour 56:155-164.

Langmore, N. E., S. Hunt, and R. M. Kilner. 2003. Escalation of a coevolutionary arms race through host rejection of brood parasitic young. Nature 422:157-160.

Lorenzana, J. C., and S. G. Sealy. 1999. A metaanalysis of the impact of parasitism by the Brown-headed Cowbird on its hosts. Pages 241-253 in Research and Management of the Brown-headed Cowbird in Western Landscapes (M. L. Morrison, L. S. Hall, S. K. Robinson, S. I. Rothstein, D. C. Hahn, and T. D. Rich, Eds.). Studies in Avian Biology, no. 18.

Loтвм, A. 1993. Learning to recognize nestlings is maladaptive for cuckoo Cuculus canorus hosts. Nature 362:743-745.

Lowther, P. E. 1995. Bronzed Cowbird (Molothrus aeneus). In The Birds of North America, no. 144 (A. Poole and F. Gill, Eds.). Academy of Natural Sciences, Philadelphia, and American Ornithologists' Union, Washington, D.C.

Nicolal, J. 1974. Mimicry in parasitic birds. Scientific American 231:92-98.

Oberholser, H. C. 1974. The Bird Life of Texas. University of Texas Press, Austin.

Ortega, C. P., and A. Cruz. 1992. Gene flow of the obscurus race into the north-central Colorado population of Brown-headed Cowbirds. Journal of Field Ornithology 63:311-317.

PAyne, R. B., J. L. Woods, and L. L. PAyne. 2001. Parental care in estrildid finches: Experimental tests of a model of Vidua brood parasitism. Animal Behaviour 62:473-483.

Pyle, P. 1997. Identification Guide to North American Birds, Part 1: Columbidae to Ploceidae. Slate Creek Press, Bolinas, California.

RothSTEIN, S. I. 1978. Geographical variation in the nestling coloration of parasitic cowbirds. Auk 95:152-160.

Rothstein, S. I. 1990. A model system for coevolution: Avian brood parasitism. Annual 
Review of Ecology and Systematics 21: 481-508.

Rothstein, S. I. 1994. The cowbird's invasion of the Far West: History, causes and consequences experienced by host species. Pages 301-315 in A Century of Avifaunal Change in North America (J. R. Jehl, Jr. and N. K. Johnson, Eds.). Studies in Avian Biology, no. 15.

Rothstein, S. I., M. A. PAtten, and R. C. Fleischer. 2002. Phylogeny, specialization, and brood parasite-host coevolution: Some possible pitfalls of parsimony. Behavioral Ecology 13:1-10.

Saino, N., R. Ambrosini, R. Matinelli, P. Ninni, AND A. P. Møller. 2003. Gape coloration reliably reflects immunocompetence of Barn Swallow (Hirundo rustica) nestlings. Behavioral Ecology 14:16-22.

Sкuтсн, А. F. 1976. Parent Birds and Their Young. University of Texas Press, Austin.

Stepney, P. H. R., and D. M. Power. 1973. Analysis of the eastward breeding expansion of Brewer's Blackbird plus general aspects of avian expansions. Wilson Bulletin $85: 452-464$.
Stevens, E. E. 1982. Variation in the oral flange color of Brown-headed Cowbird nestlings: An adaptation for brood parasitism? M.A. thesis, University of California, Santa Barbara.

Stoenr, A. M., and G. E. Hill. 2001. The effects of elevated testosterone on plumage hue in male House Finches. Journal of Avian Biology 32:153-158.

Summers, S. G., R. M. Kostecke, and G. L. Norman. 2006. Efficacy of trapping and shooting in removing breeding Brownheaded Cowbirds. Wildlife Society Bulletin 34:1107-1112.

Ward, D., and J. N. M. Smith. 1998. Morphological differentiation of Brown-headed Cowbirds in the Okanagan Valley, British Columbia. Condor 100:1-7.

Whetje, W. 2003. The range expansion of the Great-tailed Grackle (Quiscalis mexicanus Gmelin) in North America since 1880. Journal of Biogeography 30:1593-1607.

Associate Editor: R. C. Fleischer 
Copyright of Auk is the property of American Ornithologists Union and its content may not be copied or emailed to multiple sites or posted to a listserv without the copyright holder's express written permission. However, users may print, download, or email articles for individual use. 